Rev. Bras. Saúde Prod. Anim., Salvador, v.17, n.2, p.139-148 abr./jun., $2016 \quad$ http://www.rbspa.ufba.br

\title{
Digestible tryptophan-to-digestible lysine ratio in diets for laying hens of 42 to 58 weeks of age
}

\author{
Relação triptofano digestível:lisina digestivel em dietas para poedeiras de 42 a 58 semanas \\ de idade
}
CALDERANO, Arele Arlindo ${ }^{1 *}$; GOMES, Paulo Cezar ${ }^{1}$; LELIS, Guilherme Rodrigues ${ }^{1}$; DONZELE, Juarez Lopes ${ }^{1}$; BARRETO, Sérgio Luiz de Toledo ${ }^{1}$; PASTORE, Silvana Marques ${ }^{1}$; PENA, Sérgio de Miranda ${ }^{2}$

\author{
${ }^{1}$ Universidade Federal de Viçosa, Departamento de Zootecnia, Viçosa, Minas Gerais, Brasil. \\ ${ }^{2}$ Instituto Federal Sudeste de Minas Gerais, Rio Pomba, Minas Gerais, Brasil. \\ *Endereço para correspondência: arelecalderano@yahoo.com.br
}

SUMMARY

To determine the ideal digestible tryptophan-todigestible lysine ratio in diets for laying hens of 42 to 58 weeks of age, 240 Hy-Line W-36 hens at 42 weeks of age were distributed in a completely randomized design with five treatments, eight replicates and six birds per experimental unit. At 42 weeks of age, the birds were subjected to experimental treatments that consisted of diets with equal amounts of nutrients, except for the digestible tryptophan level. The digestible tryptophan levels in the experimental diets were $0.149,0.160,0.171$, 0.182 and $0.193 \%$, generating digestible tryptophanto-digestible lysine ratios of $21.5,23.1,24.6,26.2$ and $27.8 \%$. The digestible lysine level in the diets was sub-optimal (0.694\%). The same ratios between lysine and the other amino acids were maintained in all experimental diets. The ideal digestible tryptophan-to-digestible lysine ratio was estimated through the studied parameters using analysis of variance and polynomial regression analysis $(\alpha=$ 0.05 ). The digestible tryptophan-to-digestible lysine ratio in diets quadratically affected egg production, egg mass, feed conversion per egg mass and use efficiency of digestible lysine for egg mass. However, there were no effect $(\mathrm{P}>0.05)$ on egg weight, feed conversion per dozen eggs, use efficiency of digestible lysine for number of eggs produced, percentage of egg components and weight gain. The digestible tryptophan-to-digestible lysine ratio estimated for theses parameters ranged from 23.6 to $24.3 \%$. The digestible tryptophan-todigestible lysine ratio recommended in diets for laying hens of 42 to 58 weeks of age is $24.3 \%$.

Keywords: amino acid, bird, egg, ideal protein

\section{RESUMO}

Para determinar a relação ideal triptofano digestível:lisina digestível em dietas para poedeiras de 42 a 58 semanas de idade, 240 poedeiras Hy-Line W-36 com 42 semanas de idade foram distribuídas em delineamento inteiramente ao acaso com cinco tratamentos, oito repetições e seis aves por unidade experimental. Com 42 semanas de idade as aves foram submetidas aos tratamentos experimentais, que consistiram de dietas com quantidades iguais de nutrientes, exceto para o nível de triptofano digestível. Os níveis de triptofano digestível nas dietas experimentais foram 0,$149 ; 0,160 ; 0,171$; 0,182 e $0.193 \%$, gerando relações triptofano digestível:lisina digestível de 21,5;23,1; 24,6; 26,2 e $27,8 \%$. O nível de lisina digestível nas dietas foi subótimo $(0,694 \%)$. As mesmas relações entre a lisina e outros aminoácidos foram mantidas em todas as dietas experimentais. A relação ideal triptofano digestpivel:lisina digestível foi estimada por meio dos parâmetros estudados utilizando análise de variância e análise de regressão polinomial $(\alpha=$ $0.05)$. A relação triptofano digestível:lisina digestível nas dietas influenciaram quadraticamente a produção de ovos, massa de ovos, conversão alimentar e a eficiência de utilização de lisina digestível para massa de ovos. No entanto, não houve efeito $(\mathrm{P}>$ $0,05)$ sobre o peso dos ovos, conversão alimentar por dúzia de ovos, eficiência de utilização de lisina digestível para número de ovos produzidos, porcentagem dos componentes dos ovos e ganho de peso. A relação ideal triptofano digestível:lisina digestível estimada para esses parâmetros variaram de 23,6 a 24,3\%. A relação triptofano digestível:lisina digestível recomendada em dietas para poedeiras de 42 a 58 semanas de idade é $24,3 \%$.

Palavras-chave: aminoácido, aves, ovos, proteína ideal 


\section{INTRODUCTION}

Essential amino acids have an important role in the growth and production of laying hens; they are components of the body and egg proteins and important precursors of specialized products in the metabolism. Thus, the amino acid levels of diets should be precisely balanced.

Protein sources in laying hens diets have been partially replaced by industrial amino acids. This reduction is grounded in the ideal protein concept, which defines that essential amino acids should be expressed as ideal proportions relative to lysine. Lysine was chosen as the reference amino acid because it is used almost exclusively for protein deposition; it is a limiting amino acid in reducedprotein corn-soybean meal broiler diets; and its analysis is uncomplicated (BAKER, 1997). Once the ideal profile is established, the amino acids requirement of birds can be estimated from the lysine requirement. This is especially important because the absolute requirements of amino acids are largely influenced by genetic factors, production level and environmental factors, but the ratios between them are much less influenced (BREGENDAHL et al., 2008). Thus, research studies should be focused on establishment of ideal ratios between essential amino acids and lysine rather than determine the absolute requirement of the birds for each amino acid. However, the ideal profile of amino acids for commercial laying hens in the literature is not well-established.

Tryptophan is considered the third limiting amino acid in corn-soybean meal diets for laying hens (DEPONTI et al., 2007; HARMS \& RUSSELL, 2000; PEGANOVA et al., 2003; RUSSELL \& HARMS, 1999). It is the serotonin precursor and its deficiency causes birds to reduce their feed intake (PEGANOVA
\& EDER, 2003). Tryptophan is also important to alleviate the depression of weight gain and feed intake caused by niacin deficiency in poultry (Xie et al. 2014). However, few studies have been conducted with the objective to determine the requirement of digestible tryptophan and especially its ideal ratio with the digestible lysine for laying hens diets. Furthermore, the majority of studies on nutritional requirements of amino acids for laying hens are centered on the peak production, disregarding the post-peak production phase.

The objective of this study was to determine the ideal digestible tryptophanto-digestible lysine ratio in diets for laying hens of 42 to 58 weeks of age.

\section{MATERIALS AND METHODS}

The experiment was conducted at the Poultry Section of the Department of Animal Science of The Federal University of Viçosa (UFV), located in Viçosa, Minas Gerais, Brazil. The municipality is located in a tropical climatic region $\left(20^{\circ} 45^{\prime} 45^{\prime \prime} \mathrm{S}\right.$ and $4^{\circ} 52^{\prime}$ $04^{\prime \prime} \mathrm{W}$, with an altitude of $657 \mathrm{~m}$ ).

Two hundred and forty Hy-Line W-36 hens at 42 weeks of age, with initial average weight of $1,347 \mathrm{~g}$, were housed in pairs in cages $(25 \times 40 \times 45 \mathrm{~cm})$ installed in a poultry house $(12 \times 8 \mathrm{~m})$ fenced with wire mesh and covered by a clay-tile gable roof. When the birds completed 40 weeks of age, they were weighed and distributed in a completely randomized design with five treatments with six replicates of eight birds per replicate. Egg production was recorded during the period of 40-42 weeks of age. Before the experimental diets were supplied, the birds were organized in the treatments according to egg production. 
Rev. Bras. Saúde Prod. Anim., Salvador, v.17, n.2, p.139-148 abr./jun., 2016 http://www.rbspa.ufba.br ISSN 15199940

At 42 weeks of age, the birds were subjected to experimental treatments that consisted of diets with equal amounts of nutrients, except for the digestible tryptophan level. The digestible lysine level in the diets was sub-optimal $(0.694 \%)$; this suboptimal level was important to ensure that all digestible lysine consumed was used, and so that the digestible tryptophan-to-digestible lysine ratio estimated reflected the real needs of the birds. The digestible tryptophan levels in the experimental diets were 0.149 , $0.160, \quad 0.171, \quad 0.182$, and $0.193 \%$, providing digestible tryptophan-todigestible lysine ratios of 21.5, 23.1, 24.6, 26.2 , and $27.8 \%$, respectively. The animals were supplemented with Ltryptophan in substitution of L-glutamic acid in protein equivalent. After this substitution, the inert (starch) was added in the amount necessary to balance the diets. The same ratios between lysine and the other amino acids were maintained in all diets (Table 1 and 2).

The ratios between the essential amino acids and digestible lysine in the diets were: methionine + cystine, 104\%; threonine, $81 \%$; methionine, $53 \%$; valine, $93 \%$; and isoleucine, $86 \%$. The other nutrients and energy, except crude protein, followed the recommendations of Rostagno et al. (2005).

The birds were supplied with feed and water ad libitum and the lighting program adopted consisted of providing 17 hours of light per day.

The average maximum and minimum temperatures recorded inside the poultry house during the experiment were 26.5 and $14.8^{\circ} \mathrm{C}$. The experiment lasted 16 weeks. The parameters measured were: feed intake, digestible tryptophan intake, digestible lysine intake, egg production, egg weight, egg mass, feed conversion per egg mass $(\mathrm{kg} / \mathrm{kg})$ and per dozen eggs $(\mathrm{kg} / \mathrm{dz})$, use efficiency of digestible lysine for eggs mass $(\mathrm{g} / \mathrm{g})$ and for number of eggs produced (n eggs/g), percentage of egg components and weight gain.

Table 1. Composition and nutritional value of the basal diet in natural matter

\begin{tabular}{|c|c|}
\hline Composition & Basal \\
\hline Corn $(7.8 \%)$ & 61.987 \\
\hline Soybean meal $(44.3 \%)$ & 19.373 \\
\hline Corn Gluten Meal (60\%) & 1.185 \\
\hline Soybean oil & 4.546 \\
\hline Limestone & 9.780 \\
\hline Dicalcium Phosphate & 1.669 \\
\hline Salt & 0.556 \\
\hline Potassium carbonate & 0.151 \\
\hline Choline chloride $(60 \%)$ & 0.040 \\
\hline Antioxidant $^{\mathrm{a}}$ & 0.010 \\
\hline Vitamin mixture ${ }^{\mathrm{b}}$ & 0.100 \\
\hline Mineral mixture ${ }^{c}$ & 0.050 \\
\hline L-Lysine $\mathrm{HCl}(79 \%)$ & 0.075 \\
\hline DL-Methionine (99\%) & 0.280 \\
\hline L-Threonine $(98 \%)$ & 0.070 \\
\hline L-Isoleucine $(98.5 \%)$ & 0.036 \\
\hline L-Valine $(98.5 \%)$ & 0.023 \\
\hline L-Tryptophan (98\%) & - \\
\hline L-Glutamic Acid & 0.069 \\
\hline Starch & - \\
\hline \multicolumn{2}{|l|}{ Nutritional Composition $(\mathrm{g} / \mathrm{kg})$} \\
\hline Crude Protein $(\%)$ & 14.5 \\
\hline Metabolizable Energy (kcal/kg) & 3,000 \\
\hline Calcium (\%) & 4.230 \\
\hline Available Phosphorus (\%) & 0.395 \\
\hline Potassium (\%) & 0.615 \\
\hline Chloride (\%) & 0.373 \\
\hline Sodium $(\%)$ & 0.237 \\
\hline Digestible Tryptophan (\%) & 0.149 \\
\hline Digestible Lysine $(\%)$ & 0.694 \\
\hline Digestible Met+Cys (\%) & 0.722 \\
\hline Digestible Methionine (\%) & 0.503 \\
\hline Digestible Threonine (\%) & 0.562 \\
\hline Digestible Isoleucine (\%) & 0.597 \\
\hline Digestible Valine (\%) & 0.645 \\
\hline
\end{tabular}

${ }^{\mathrm{a}}$ Butylated hydroxytoluene; ${ }^{\mathrm{b}}$ Quantity per $\mathrm{kg}$ of feed: vit. A - 7,200 UI; vit $\mathrm{D}_{3}-1,600 \mathrm{UI}$; vit. E - 5 UI; vit $\mathrm{B}_{1}-0.9 \mathrm{mg}$; vit $\mathrm{B}_{2}-2.7 \mathrm{mg}$; vit $\mathrm{B}_{6}-$ $1.5 \mathrm{mg}$; calcium pantothenate $-5.9 \mathrm{mg}$; biotin $0.02 \mathrm{mg}$; vit. $\mathrm{K}_{3}-1.1 \mathrm{mg}$; folic acid $-0.25 \mathrm{mg}$; niacin - 16mg; vit. $\mathrm{B}_{12}-7.2 \mathrm{mcg}$; selenium $0.25 \mathrm{mg}$; 'Quantity per kg of feed: manganese $75 \mathrm{mg}$; iron - 50mg; zinc - 70mg; copper - 8mg; iodine $-0.75 \mathrm{mg}$. 
Rev. Bras. Saúde Prod. Anim., Salvador, v.17, n.2, p.139-148 abr./jun., 2016 http://www.rbspa.ufba.br ISSN 15199940

Table 2. Addition of L-Tryptophan, L-Glutamic acid and starch added in each treatment

\begin{tabular}{lccccc}
\hline Digestible tryptophan level & 0.149 & 0.160 & 0.171 & 0.182 & 0.193 \\
\hline L-Tryptophan (98\%) & - & 0.011 & 0.023 & 0.034 & 0.045 \\
L-Glutamic Acid & 0.069 & 0.053 & 0.034 & 0.018 & - \\
Starch & - & 0.005 & 0.012 & 0.017 & 0.024 \\
\hline
\end{tabular}

The ideal digestible tryptophan-todigestible lysine ratio was estimated through the parameters studied using analysis of variance and polynomial regression analysis (the sum square of treatment was decomposed in sum square of tested regression model). We opted to test linear and quadratic regression model given the biological interpretation of the parameter estimates from these models. The models were compared by F-test and $\mathrm{R}^{2}$. A confidence interval of $95 \%$ was calculated for the parameters with significant quadratic effect. The probability value adopted was $\alpha=0.05$. Analyses were performed on statistical analysis system SAEG version 9.1 (2007).

\section{RESULTS AND DISCUSSION}

The digestible tryptophan intake of the birds increased $(\mathrm{P}<0.05)$ as the digestible tryptophan-to-digestible lysine ratio in the diets was elevated. Hens consumed between 133.8 and $168.9 \mathrm{mg} /$ day of digestible tryptophan. However, the tryptophan-to-digestible lysine ratio had no influence $(\mathrm{P}>0.05)$ on feed intake or digestible lysine intake (Table 3). The birds fed the lowest digestible tryptophanto-digestible lysine ratio ingested $133 \mathrm{mg} /$ day of digestible tryptophan. Despite the known role of the tryptophan as a precursor of serotonin - the neurotransmitter to which the function of regulating appetite in birds has been attributed - the observed tryptophan intake was not low enough to suppress the feed intake or the birds ingest more feed in an attempt to achieve the required consumption of tryptophan that was deficient in the diet. Thus, the increase in the digestible tryptophan intake observed was largely due to the increase in the digestible tryptophan content in the diets. Deponti et al. (2007) came to the same conclusion and observed that the intake of $137 \mathrm{mg} / \mathrm{bird} /$ day was not low enough to influence the feed intake of laying hens.

Egg production, egg mass, feed conversion per egg mass and use efficiency of digestible lysine for eggs mass were quadratically affected $(\mathrm{P}<0.05)$ by the digestible tryptophanto-digestible lysine ratios (Figure 1 - 4). For the feed conversion per egg mass and use efficiency of digestible lysine for eggs mass there was a linear effect of the digestible tryptophan-todigestible lysine ratios, however the quadratic model showed the best fit of the data with the highest $\mathrm{R}^{2}$.

When the digestible tryptophan-todigestible lysine ratios in the diets increased from 21.5 to $24.6 \%$, egg production increased by $3.93 \%$. For this parameter, the ideal level of digestible tryptophan estimated was $0.172 \%$, according to the equation: $\hat{\mathrm{y}}=-65.299$ $+1708.5 \mathrm{x}-4970.6 \mathrm{x}^{2}\left(\mathrm{R}^{2}=0.17\right)$. This level corresponded to the intake of 153 $\mathrm{mg} / \mathrm{bird} /$ day of digestible tryptophan and a digestible tryptophan-to-digestible lysine ratio of $24.8 \%$. Applying the confidence interval of $95 \%$ to the quadratic response equation we obtained the ratio of $23.6 \%$. 
Table 3. Performance of laying hens from 42 to 58 weeks of age fed with diets containing different ratios digestible tryptophan:digestible lysine

\begin{tabular}{|c|c|c|c|c|c|c|c|c|}
\hline \multirow{2}{*}{ Parameter } & \multicolumn{5}{|c|}{$\begin{array}{c}\text { Digestible tryptophan-to-digestible lysine ratio } \\
(\%)\end{array}$} & \multirow{2}{*}{$\begin{array}{l}\text { CV } \\
(\%)\end{array}$} & \multicolumn{2}{|c|}{ P Value } \\
\hline & 21.5 & 23.1 & 24.6 & 26.2 & 27.8 & & $\mathrm{~L}^{\mathrm{a}}$ & $Q^{b}$ \\
\hline Feed intake (g/bird/day) & 89.78 & 88.48 & 90.34 & 87.69 & 87.50 & 3.16 & 0.097 & 0.542 \\
\hline Digestible tryptophan intake (mg/bird/day) & 133.8 & 141.6 & 154.5 & 159.6 & 168.9 & 3.26 & 0.000 & 0.465 \\
\hline Digestible lysine intake (mg/bird/day) & 623.1 & 614.0 & 626.9 & 608.6 & 607.3 & 3.16 & 0.097 & 0.542 \\
\hline Egg production $(\%)$ & 79.11 & 80.18 & 82.22 & 80.67 & 79.33 & 3.67 & 0.776 & 0.038 \\
\hline Egg weight (g) & 59.82 & 59.64 & 60.72 & 60.10 & 60.12 & 2.37 & 0.508 & 0.499 \\
\hline Egg mass (g/bird/day) & 47.30 & 47.81 & 49.92 & 48.50 & 47.69 & 4.01 & 0.503 & 0.022 \\
\hline Feed conversion per egg mass $(\mathrm{g} / \mathrm{g})$ & 1.899 & 1.852 & 1.811 & 1.810 & 1.835 & 2.90 & 0.007 & 0.013 \\
\hline Feed conversion per dozen eggs (kg/dozen $)$ & 1.363 & 1.323 & 1.319 & 1.305 & 1.324 & 3.44 & 0.065 & 0.078 \\
\hline Use efficiency of digestible lysine for eggs mass $(\mathrm{g} / \mathrm{g})$ & 75.952 & 77.860 & 79.651 & 79.657 & 78.552 & 2.89 & 0.009 & 0.013 \\
\hline $\begin{array}{l}\text { Use efficiency of digestible lysine for number of eggs }\left(n^{\circ}\right. \\
\text { eggs/g) }\end{array}$ & 1.271 & 1.308 & 1.313 & 1.327 & 1.307 & 3.39 & 0.078 & 0.081 \\
\hline Percentage of yolk (\%) & 26.25 & 26.23 & 26.27 & 25.91 & 26.19 & 3.19 & 0.635 & 0.851 \\
\hline Percentage of albumen (\%) & 64.38 & 64.45 & 64.24 & 64.81 & 64.42 & 1.28 & 0.636 & 0.894 \\
\hline Percentage of shell $(\%)$ & 9.37 & 9.31 & 9.49 & 9.29 & 9.39 & 3.36 & 1.000 & 0.883 \\
\hline Weight gain (g/bird) & 66.14 & 44.80 & 69.44 & 60.58 & 36.90 & 84.92 & 0.424 & 0.545 \\
\hline
\end{tabular}

${ }^{\mathrm{a}}$ Linear effect; ${ }^{\mathrm{b}}$ Quadratic effect. 
Rev. Bras. Saúde Prod. Anim., Salvador, v.17, n.2, p.139-148 abr./jun., 2016 http://www.rbspa.ufba.br ISSN 15199940

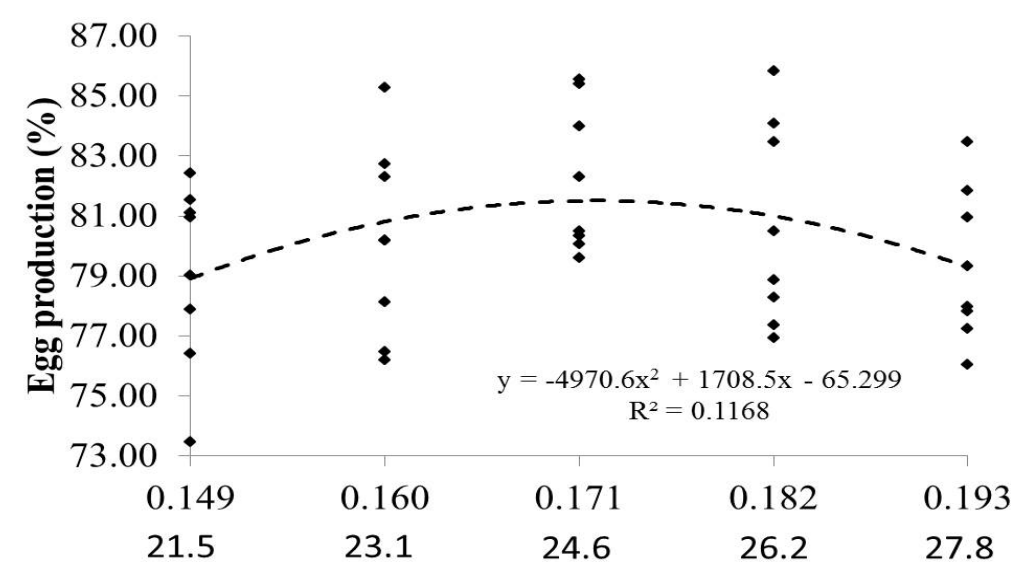

Dig. tryptophan and tryptophan-to-lysine ratios

Figure 1. Effect of digestible tryptophan-to-digestible lysine ratio in the diet on egg production

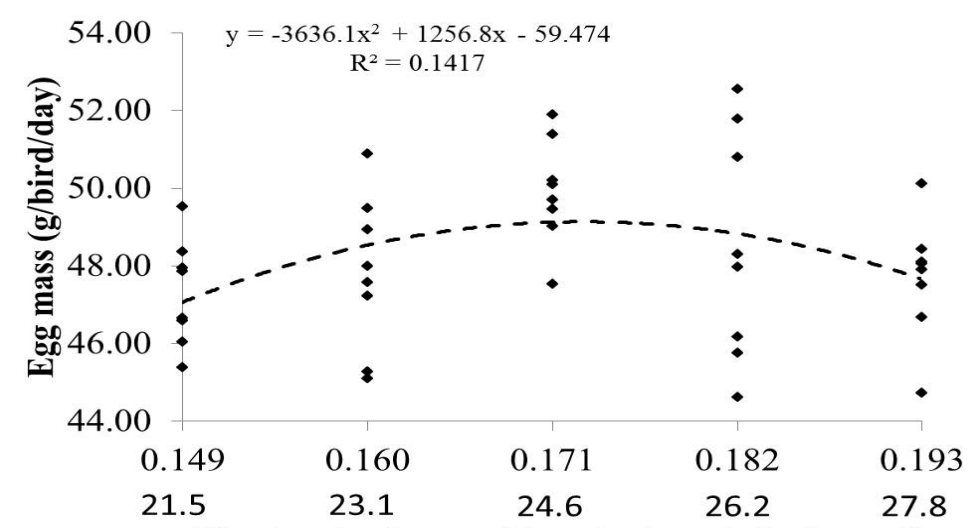

Dig. tryptophan and tryptophan-to-lysine ratios

Figure 2. Effect of digestible tryptophan-to-digestible lysine ratio in the diet on egg mass

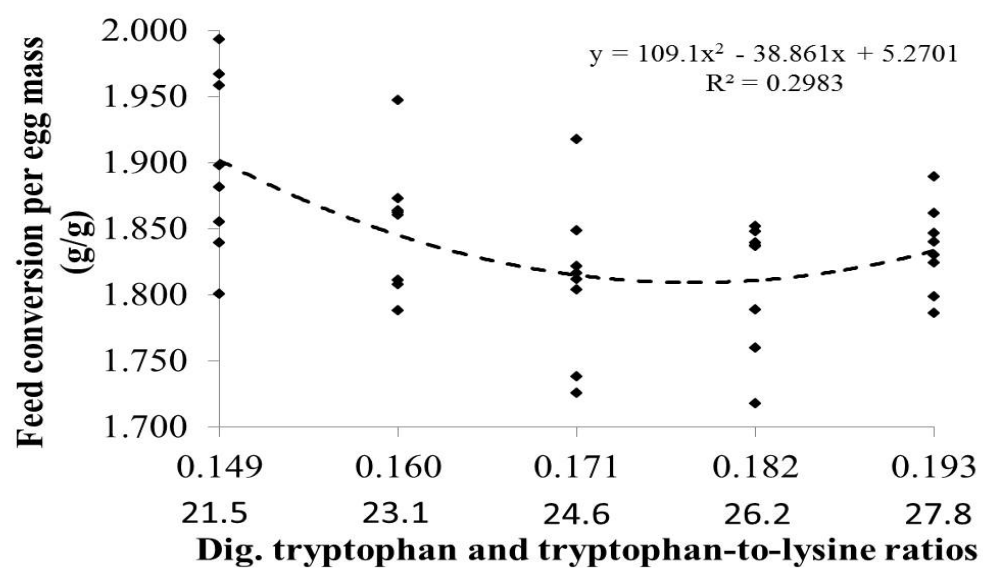

Figure 3. Effect of digestible tryptophan-to-digestible lysine ratio in the diet on feed conversion per eggs mass 
Rev. Bras. Saúde Prod. Anim., Salvador, v.17, n.2, p.139-148 abr./jun., 2016 http://www.rbspa.ufba.br

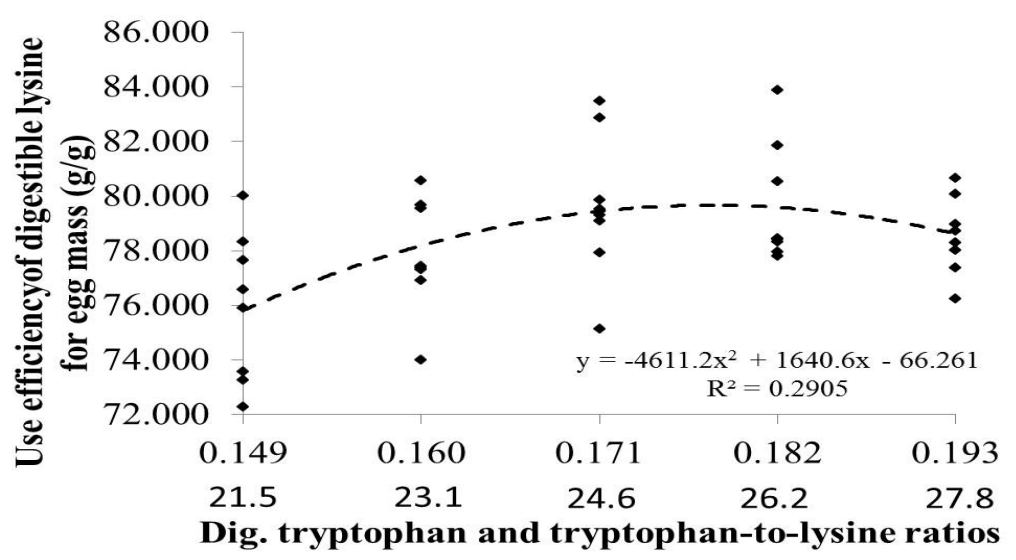

Figure 4. Effect of digestible tryptophan-to-digestible lysine ratio in the diet on use efficiency of digestible lysine for egg mass

The ideal digestible tryptophan-todigestible lysine ratio of $23.6 \%$ estimated in this study for egg production was close to the $24.0 \%$ estimated for the same parameter by Lima et al. (2012), who studied the tryptophan-to-digestible ratios of $19,21,23,25$ and $27 \%$ in diets. The overall average egg production in the present study was $80.3 \%$, which is below the expected according to the strain manual. This fact can be explained by the suboptimal level of digestible lysine used in the diets. Similarly, Brumano et al. (2010) and Reis et al. (2011), to estimate ideal ratios between essential amino acids and lysine for birds, also used suboptimal levels of digestible lysine in the diet. The suboptimal level is important to ensure that all digestible lysine consumed by birds are actually used and the digestible tryptophan-to-digestible lysine ratio is estimated accurately. A higher amount of dietary digestible lysine than what birds can use may lead to an underestimated digestible tryptophan-to-digestible lysine ratio. Because the objective with the study was to determine the ideal digestible tryptophan-to-digestible lysine ratio and not the absolute requirement of digestible tryptophan as $\mathrm{mg} / \mathrm{bird} /$ day, this lower egg production did not influence the reliability of estimates.

Egg mass increased from 47.30 to $49.92 \mathrm{~g} / \mathrm{bird} /$ day when the digestible tryptophan-to-digestible lysine ratio in the diets was increased from 21.5 to $24.6 \%$. The level of digestible tryptophan that maximized egg mass was $0.173 \%$, which corresponded to the intake of 154 $\mathrm{mg} /$ bird/day of digestible tryptophan and a digestible tryptophan-to-digestible lysine ratio of $24.9 \%$. $95 \%$ of this response was $23.7 \%$. The equation for egg mass was: $\hat{\mathrm{y}}=-59.474+1256.8 \mathrm{x}-$ $3636.1 \mathrm{x}^{2}\left(\mathrm{R}^{2}=0.14\right)$.

The effect of digestible tryptophan-todigestible lysine ratios observed on egg mass reflected the effect found in egg production. This finding was similar to that observed by other authors, who also noted the influence of tryptophan levels in the diet on the egg mass (PEGANOVA et al. 2003; RUSSELL \& HARMS 1999). However, Russell \& Harms (1999) observed that only levels of tryptophan lower than or equal to $0.130 \%$ promoted reduction in the egg mass produced by laying hens of 55 to 59 weeks of age. The ideal ratio of $24.3 \%$ estimated for feed conversion per egg mass, found in the present study, was similar to the $24.6 \%$ 
obtained by Lima et al. (2012) for the same parameter.

Feed conversion per egg mass improved by $4.67 \%$ when the digestible tryptophanto-digestible lysine ratios in the diets were increased from 21.5 to $26.2 \%$. The optimal digestible tryptophan level estimated was $0.178 \%$, according to the equation: $\hat{\mathrm{y}}=5.2701-38.861 \mathrm{x}+109.1 \mathrm{x}^{2}$ $\left(\mathrm{R}^{2}=0.30\right)$. This level corresponded to the intake of $158 \mathrm{mg} / \mathrm{bird} /$ day of digestible tryptophan and to a digestible tryptophan-to-digestible lysine ratio of $25.6 \%$. The confidence limit of $95 \%$ to the quadratic response equation resulted in the ratio of $24.3 \%$.

Increasing the digestible tryptophan-todigestible lysine ratio from 21.5 to $26.2 \%$ caused the egg mass produced per each gram of digestible lysine consumed to increase from 75.952 to $79.657 \mathrm{~g}$. The equation estimated for the use efficiency of digestible lysine for egg mass was: $\hat{y}=$ $-66.261+1640.6 \mathrm{x}-4611.2 \mathrm{x}^{2}\left(\mathrm{R}^{2}=\right.$ $0.29)$. The level of digestible tryptophan that maximized this parameter was $0.178 \%$. This level corresponded to the intake of $158 \mathrm{mg} / \mathrm{bird} /$ day of digestible tryptophan and a digestible tryptophan-todigestible lysine ratio of $25.6 \%$. Applying the confidence interval of $95 \%$ to the quadratic response equation, we obtained the ratio of $24.3 \%$.

As occurred in this present study, in experiments aimed to establish ideal ratios between essential amino acids and lysine, it is ideal that the feed intake of the birds for different treatments not present significant variation. A variation in feed intake results in variation in the amount of digestible lysine consumed, which could influence the performance parameters and mask the estimated ideal ratio. In these cases, the use efficiency of digestible lysine for egg mass can be an important parameter to help isolate the effect of digestible tryptophan on bird performance. Thus, the level of digestible tryptophan in the diet which maximizes egg mass and/or the number of eggs per gram of digestible lysine consumed is the one that establishes the best-fit or ideal digestible tryptophan-to-digestible lysine ratio. In the present study, the ideal digestible tryptophan-to-digestible lysine ratio for this parameter was $24.3 \%$.

The digestible tryptophan-to-digestible lysine ratio had no significant effect $(\mathrm{P}>0.05)$ on egg weight, feed conversion per dozen eggs, use efficiency of digestible lysine for number of eggs produced, percentage of egg components and weight gain. Thus, the intake of $134 \mathrm{mg} /$ bird/day of digestible tryptophan or the digestible tryptophan-to-digestible lysine ratio of $21.5 \%$ was sufficient to maintain theses parameters. Similarly to the present study, Deponti et al. (2007) concluded that the egg weight, percentage of yolk and albumen and the total solids content of yolk and albumen of the eggs from laying hens are not influenced by ingestion of tryptophan in levels of 137.1 to $228.0 \mathrm{mg} /$ bird/day. Antar et al. (2004) also concluded that egg weight was not affected when the hens diets contained 0.166 or $0.176 \%$ of tryptophan.

The estimated digestible tryptophan-todigestible lysine ratio, considering the studied parameters, ranged from 23.6 to $24.3 \%$. Taking the feed conversion per egg mass into account, the estimated ideal digestible tryptophan-to-digestible lysine ratio was $24.3 \%$. This value was similar to the $24.6 \%$ estimated by Lima et al. (2012) based on the feed conversion per egg mass of hens of 29 to 45 weeks of age. This ratio was higher than the values obtained by Deponti et al. (2007), who concluded that depending on the trait (production or egg mass) and on the regression model applied on data analyses (quadratic, exponential or segmented), the ideal tryptophan-tolysine ratios for laying hens of 53 to 58 weeks of age are in the range of 17.4 to 
Rev. Bras. Saúde Prod. Anim., Salvador, v.17, n.2, p.139-148 abr./jun., 2016 http://www.rbspa.ufba.br ISSN 15199940

$20.3 \%$. However, the authors adopted the methionine + cystine-to-lysine ratio of $81 \%$. In a recent research study with laying hens, Brumano et al. (2010) estimated an ideal digestible methionine + cystine-to-digestible lysine ratio of $101 \%$ for laying hens of 42 to 58 weeks of age. It should be noted that even though the birds still have the potential to respond to increase in the digestible tryptophan-to-digestible lysine ratio in the diet, the performance gain may be limited if the ratios between other essential amino acids and digestible lysine are underestimated, and this may lead to underestimation of the digestible tryptophan-to-digestible lysine ratio. The digestible tryptophan-to-digestible lysine ratio estimated in this study was also higher than the $22.3 \%$ estimated by Bregendahl et al. (2008) for optimal egg mass by hens of 28 to 34 weeks of age. However, these authors used increasing levels of digestible lysine in the experimental diets, which can also make the estimate of the digestible tryptophan-to-digestible lysine ratio subjective.

The ideal digestible tryptophan-todigestible lysine ratio recommended in diets for laying hens of 42 to 58 weeks of age is $24.3 \%$.

\section{REFERENCES}

ANTAR, R.S.; HARMS, R.H.; SHIVAZAD, M.; FARIA, D.E.; RUSSELL, G.B. Performance of commercial laying hens when six percent corn oil is added to the diet at various ages and with different levels of tryptophan and protein. Poultry

Science, v.83, n.3, p.447-455, 2004.
BAKER, D.H. Ideal amino acid profiles for swine and poultry and their applications in feed formulation.

BioKyowa Technology Review, v.9, p.1-24, 1997.

BREGENDAHL, K.; ROBERTS, S.A.; KERR, B.; HOEHLER, D. Ideal ratios of isoleucine, methionine, methionine plus cystine, threonine, tryptophan, and valine relative to lysine for white leghorn-type laying hens of twentyeight to thirty-four weeks of age.

Poultry Science, v.87, n.4, p.744-758, 2008.

BRUMANO, G.; GOMES, P.C.; DONZELE, J.L.; ROSTAGNO, H.S.; ROCHA, T.C.; MELLO, H.H.C. Níveis de metionina + cistina digestível para poedeiras leves no período de 42 a 58 semanas de idade. Revista Brasileira de Zootecnia, v.39, n.9, p.1984-1992, 2010 .

DEPONTI, B.J.; FARIA, D.E.; FARIA FILHO, D.E.; ROMBOLA, L.G.; ARAUJO, L.F.; JUNQUEIRA, O.M. Exigências de triptofano e padrão de recuperação do desempenho de poedeiras comerciais após alimentação com rações deficientes em triptofano.

Revista Brasileira de Zootecnia, v.36, n.5, p.1324-1330, 2007.

HARMS, R.H.; RUSSELL, G.B.

Evaluation of tryptophan requirement of the commercial layer by using a cornsoybean meal basal diet. Poultry Science, v.79, n.5, p.740-742, 2000.

LIMA, M.R.; COSTA, F.G.P.; GUERRA, R.R.; SILVA, J.H.V.; RABELO, C.B.V.; MIGLINO, M.A.; NOGUEIRA, E.T.; PINHEIRO, S.G. Digestible tryptophan:lysine ratio for laying hens. Revista Brasileira de Zootecnia, v.41, n. 10, p.2203-2210, 2012. 
Rev. Bras. Saúde Prod. Anim., Salvador, v.17, n.2, p.139-148 abr./jun., 2016 http://www.rbspa.ufba.br

PEGANOVA, S.; EDER, K.

Interactions of various supplies of isoleucine, valine, leucine and

tryptophan on the performance of laying hens. Poultry Science, v.82, n.1, p.100105, 2003.

PEGANOVA, S.; HIRCHE, F.; EDER, $\mathrm{K}$. Requirement of tryptophan in relation to the supply of large neutral amino acids in laying hens. Poultry Science, v.82, n.5, p.815-822, 2003.

REIS, R.S.; BARRETO, S.L.T.; ABJAUDE, W.S.; LIMA, H.J.D.; MEDINA, P.M.; FERREIRA, F.

Relationship of methionine plus cystine with lysine in diets for laying Japanese quails. Revista Brasileira de Zootecnia, v.40, n.5, p.1031-1037, 2011.

ROSTAGNO, H.S.; ALBINO, L.F.T.; DONZELE, J.L.; GOMES, P.C.; OLIVEIRA, R.F. LOPES, D.C.; FERREIRA, A.S.; BARRETO, S.L.T.; EUCLIDES, R.F. Tabelas brasileiras para aves e suínos: composição de alimentos e exigências nutricionais, Viçosa: Universidade Federal de Viçosa, 2005. 186p.

RUSSELL, G.B.; HARMS, R.H. Tryptophan requirement of the commercial hen. Poultry Science, v.78, n.9, p.1283-1285, 1999.

SAEG. Sistema para Análises Estatísticas. Versão 9.1. Viçosa: Fundação Arthur Bernardes, 2007.

XIE, M.; HAN, X.F.; HUANG, W.; HOU, S.S. Effects of niacin status on tryptophan requirements of starter white Pekin ducks. Livestock Science, v.159, p.75-78, 2014.

Data de recebimento: $20 / 10 / 2014$

Data de aprovação: 27/04/2016 